\title{
Electrophilic Reaction on Plinol C and Syntheses of Functionalized 2-Oxabicyclo[2,2,1]heptane Derivatives
}

\author{
Katsumi KaKinuma, * Noriaki Yamauchi and Yoshinori Fujimoto \\ Department of Chemistry, Tokyo Institute of Technology, \\ O-okayama, Meguro-ku, Tokyo 152, Japan \\ Received March 3, 1988
}

\begin{abstract}
New functionalized 2-oxabicyclo[2,2,1]heptane derivatives were synthesized for their potential biological activities by way of the intramolecular ether bond formation of plinol $\mathrm{C}$ that was obtained from linalool by a thermal ene reaction. The mechanism for the ether-forming reactions is discussed.
\end{abstract}

During the last decade, much attention has been focused on various physiological activities of cyclopentanoids and derivatives of related fused-ring systems, especially those of prostacyclines and thromboxanes. Along these lines, it seemed appropriate to explore some other "oxabicyclo"-cyclopentanoids for their biological interest and we undertook the preparation of a series of compounds containing a 2-oxabicyclo[2,2,1]heptane ring system with suitable functional groups, based on an interest in the stereo- and regio-chemical outcome of the cyclization of plinol $\mathrm{C}$ and an expectation of some biological activities. ${ }^{1)}$

Although stereoisomers of 3,3,7-trimethyl2-oxabicyclo[2,2,1]heptane have been reported as minor products from the oxymercurationdemercuration reaction of linalool, ${ }^{1}$ those products seemed to be insufficient for further conversion. We attempted to construct the desired 2-oxabicyclo[2,2,1]heptane system from plinol C (2), ${ }^{3)}$ which could be prepared by the pyrolytic ene reaction of linalool (1). Racemic plinol C (2) was thus prepared according to the literature procedures with a slight modification. ${ }^{4 \sim 6)}$

A crucial and intriguing feature for creating a 2-oxabicyclo[2,2,1]heptane ring system from 2 was the stereo- and regio-chemistry of the electrophilic addition reaction. ${ }^{7)}$ Various reaction conditions were attempted to see what the stereochemical outcomes were. Before carrying out the reactions, the ground state conformational energies of the conformers $\mathbf{A}$ and B (Fig. 1) were calculated by a molecular mechanics approach (MM2) ${ }^{8}$ Little energy difference $(0.86 \mathrm{kcal} / \mathrm{mol})$ and the small rotational barrier $(4.2 \mathrm{kcal} / \mathrm{mol})$ between these conformers suggested less selective reactions upon this olefin (2) and the probable formation of a mixture of products.

Treatment of $\mathbf{2}$ with either $\mathrm{N}$-iodosuccinimide or $N$-bromosuccinimide in acetonitrile at room temperature gave $\mathbf{4 a}$ or $\mathbf{4 b}$ exclusively, ${ }^{9)}$ the numbering system being assigned arbitrarily as shown in Scheme 2. The 2oxabicyclo[2,2,1]heptane structures of $\mathbf{4 a}$ and 4b rather than 2-oxabicyclo[3,2,1]octane were first confirmed by the ${ }^{13} \mathrm{C}-\mathrm{NMR}$ spectrum, i.e. carbons being involved in the ether linkage were observed at $80.7 \mathrm{ppm}$ and $87.6 \mathrm{ppm}$ in $\mathbf{4 a}$,

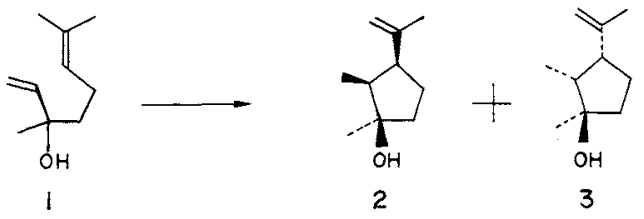

SCHEME 1.

* To whom all correspondence should be addressed. 


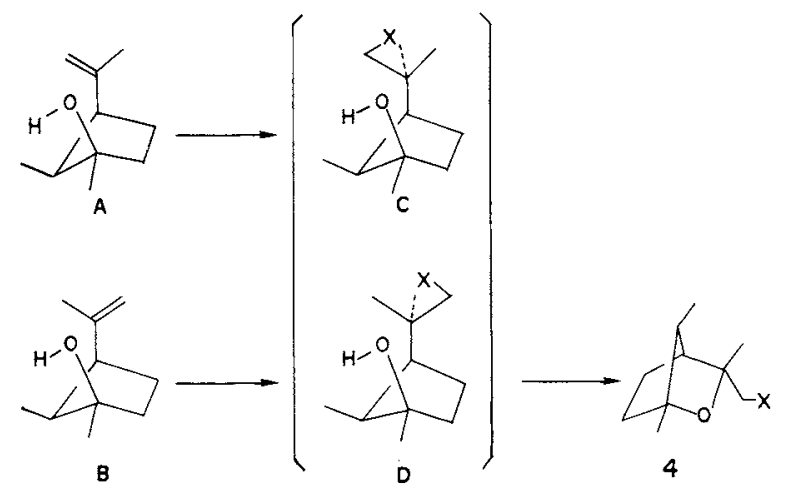

FIG. 1.

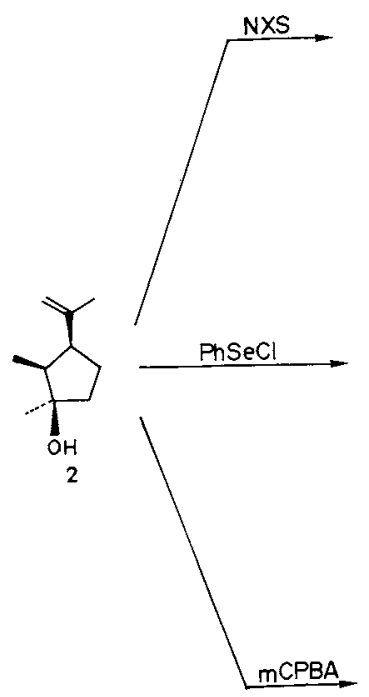<smiles>C[C@H]1CC[C@](C)(O)C1(C)C</smiles><smiles>[X]C1(C)OC2(C)CCC1(C)C2([Y])C</smiles>

4a $x=1$ b $X=B r$<smiles>CC12CCC(O1)C(C)(CSc1ccccc1)C2(C)C</smiles><smiles>CC1C(C)C2(C)CCC1C(C)(CSc1ccccc1)O2</smiles><smiles>C[C@@H]1C(C)(C(F)(F)F)CC[C@]1(C)O</smiles><smiles>C1C[SbH2]C[SnH2]1</smiles><smiles>CC1(CO)OC(C)(CO)C2(C)CCC1CC2</smiles>

SCHEME 2.

and at $81.2 \mathrm{ppm}$ and $87.0 \mathrm{ppm}$ in $\mathbf{4 b}$ as quaternary carbons when judged by INEPT experiments. The stereochemistry of $\mathbf{4 a}$ was deduced from the ${ }^{1} \mathrm{H}-\mathrm{NMR}$ analysis. The $\mathrm{C}-11$ methyl signal was assigned to a doublet at $1.48 \mathrm{ppm}$ $(J=1.22 \mathrm{~Hz})$ because the signal was long-range coupled with a proton at $3.10 \mathrm{ppm}(J=1.22$ and $10 \mathrm{~Hz}$ ) of the $\mathrm{C}-10$ methylene group. The remaining two methyl signals were observed at $1.14 \mathrm{ppm}\left(\mathrm{d}, J=8 \mathrm{~Hz}, 8-\mathrm{CH}_{3}\right)$ and at $1.18 \mathrm{ppm}$ (s, $9-\mathrm{CH}_{3}$ ). Next, use was made of the nuclear Overhauser effect (NOE). Upon irradiation to a methyl signal at 1.14 ppm (C-8), a NOE enhancement was observed on the signal at $1.48 \mathrm{ppm}$ (C-11) using a difference spectrum method, the singlet methyl signal at $1.18 \mathrm{ppm}$ (C-9) remaining unchanged. The structure of $4 \mathrm{~b}$ was similarly assigned.

In contrast, phenylselenoetherification of 2 initiated by phenylselenenyl chloride in $\mathrm{CH}_{2} \mathrm{Cl}_{2}$ at $0^{\circ} \mathrm{C}$ gave in a $71 \%$ yield an approximately 5:6 mixture of 5 and $\mathbf{6}$ as judged by their isolation. ${ }^{10)}$ The 2-oxabicyclo[2,2,1]heptane structures of the prod- 
ucts were again confirmed by ${ }^{13} \mathrm{C}-\mathrm{NMR}$ INEPT spectra, i.e. two quaternary oxygenated $\mathrm{sp}^{3}$ carbon signals were observed at $82.3 \mathrm{ppm}$ and $86.3 \mathrm{ppm}$ in $\mathbf{5}$, and at $81.4 \mathrm{ppm}$ and 86.4 ppm in 6 . The stereochemistry at the C-3 position of 5 and 6 was deduced in a similar manner to that already discussed. Thus, the one in which irradiation of a doublet methyl signal at $1.07 \mathrm{ppm}$ enhanced the methylene double doublet signal at 2.97 and 3.34 ppm was assigned to $\mathbf{5}$, and the other in which irradiation of a doublet methyl signal at 1.14 ppm enhanced a broad methyl singlet at 1.38 ppm was assigned to 6 .

This difference of reactivity between the haloetherification and phenylselenoetherification deserves noting. The haloetherification was almost stereospecific and this seemed to have been due to the stereoelectronic effect. Thus, an inspection of the molecular models implied that the attacking hydroxyl group in the intermediate $\mathbf{D}$ could align linearly to the elongating carbon-halogen bond on the opposite side so that the displacement reaction was facilitated, whereas this was not the case in the intermediate $\mathbf{C}$. The C-8 methyl group might have had a steric effect to some extent, but details are not clear at present. On the contrary, phenylselenoetherification may have proceeded kinetically through immediate attack of the hydroxyl group to the developing highly reactive selenenium center, giving rise to a mixture of isomers in a ratio reflecting the population of conformers $\mathbf{A}$ and $\mathbf{B}$.

Epoxydation was also examined by a standard procedure with $m$-chloroperbenzoic acid in $\mathrm{CH}_{2} \mathrm{Cl}_{2}$ solvent. The ${ }^{1} \mathrm{H}-\mathrm{NMR}$ spectrum of the extracted products revealed that the resulting epoxides were obtained as a 1:1 mixture of 7 and 8 . The product mixture was not separated into individual isomers, but was rather treated with $10 \mathrm{~mol} \%$ of pyridinium $p$ toluenesulfonate to give, along with various by-products, a mixture of the bicyclic alcohols, which were separated by preparative TLC to give 9 and 10 in $11 \%$ and $36 \%$ yields, respectively.

The strucrures of $\mathbf{9}$ and $\mathbf{1 0}$ were again

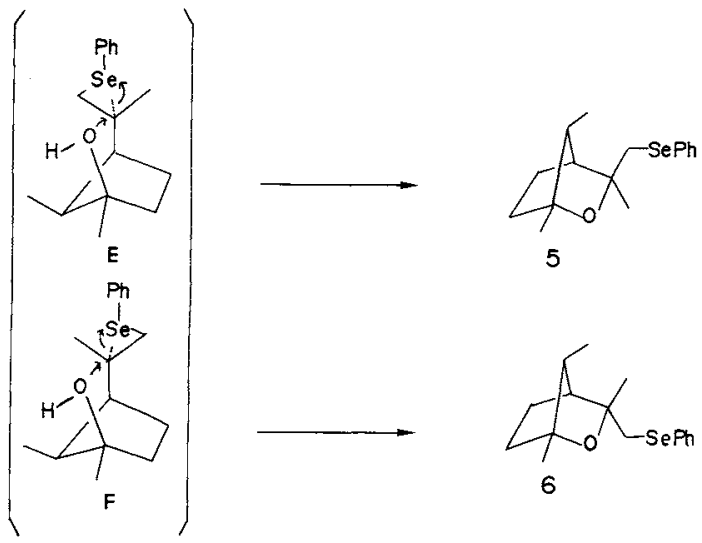

FIG, 2.

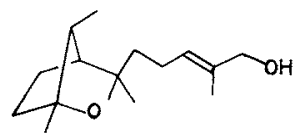

II

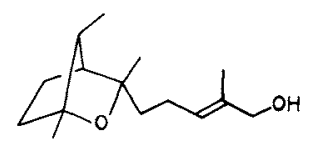

12
FIG. 3.

determined by making use of ${ }^{13} \mathrm{C}-\mathrm{NMR}$ INEPT techniques and ${ }^{1} \mathrm{H}-\mathrm{NMR}$ NOE experiments. Thus, the major isomer (more polar) was assigned to be 10 , since, in the ${ }^{13} \mathrm{C}-\mathrm{NMR}$ spectrum, the carbons being involved in the ether linkage were observed at $81.3 \mathrm{ppm}$ and 85.6 ppm as quaternary carbons, while a hydroxymethyl carbon resonated at $69.3 \mathrm{ppm}$. In addition, irradiation to a doublet signal at 1.13 ppm in the ${ }^{1} \mathrm{H}-\mathrm{NMR}$ spectrum showed an NOE on the signal of a broad singlet at 1.30 ppm, but not on the methylene protons resonating at $3.45 \mathrm{ppm}$ and $3.54 \mathrm{ppm}$. The less polar compound, which showed an $A B$ type of double doublet at $3.22 \mathrm{ppm}$ and $3.67 \mathrm{ppm}$, was assigned to 9 , because irradiation of a doublet methyl signal at $1.07 \mathrm{ppm}$ induced an NOE enhancement of a signal at $3.67 \mathrm{ppm}$. The expected NOE effect on the signal at $3.22 \mathrm{ppm}$ was little, suggesting a rather restricted rotation of the bond between C-3 and C-11, possibly due to hydrogen bonding. A complementary result of the enhancement of a methyl signal at $1.07 \mathrm{ppm}$ by irradiating the signal at 3.67 ppm further supported this assignment.

The functionalized 2-oxabicyclo[2,2,1]hep- 


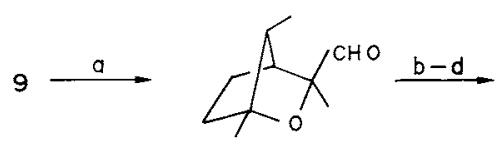

13

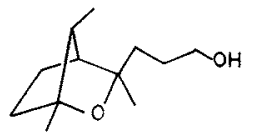

16

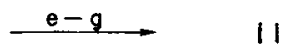

SCHEME 3. a, PCC/CH $\mathrm{Cl}_{2} ; \mathrm{b}, \mathrm{Ph}_{3} \mathrm{P}=\mathrm{CHCO}_{2} \mathrm{C}_{2} \mathrm{H}_{5} /$ benzene; $\mathrm{c}, \mathrm{H}_{2} / 5 \% \mathrm{Pd}-\mathrm{C} ; \mathrm{d}, \mathrm{LiAlH}_{4} / \mathrm{THF} ; \mathrm{e}, \mathrm{PCC} /$ $\mathrm{CH}_{2} \mathrm{Cl}_{2} ; \mathrm{f}, \mathrm{Ph}_{3} \mathrm{P}=\mathrm{C}\left(\mathrm{CH}_{3}\right) \mathrm{CO}_{2} \mathrm{C}_{2} \mathrm{H}_{5} /$ benzene; g, DIBAH/THF.

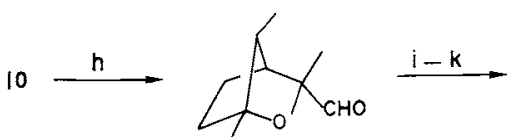

19

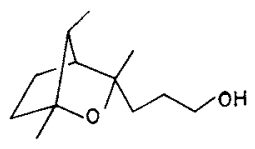

22

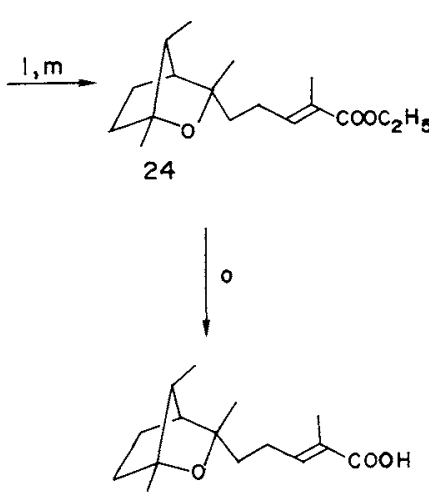

25

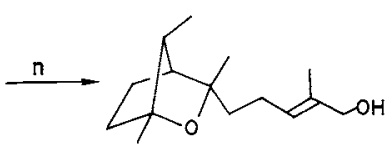

12

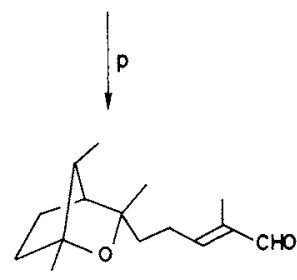

26

SCHEME 4. h, PCC/CH $\mathrm{Cl}_{2} ; \mathrm{i}, \mathrm{Ph}_{3} \mathrm{P}=\mathrm{CHCO}_{2} \mathrm{C}_{2} \mathrm{H}_{5} ; \mathrm{j}, \mathrm{H}_{2} / 10 \% \mathrm{Pd}-\mathrm{C} ; \mathrm{k}, \mathrm{LiAlH}_{4} / \mathrm{THF} ; \mathrm{l}, \mathrm{PCC} \mathrm{CH}_{2} \mathrm{Cl}_{2}$; $\mathrm{m}, \mathrm{Ph}_{3} \mathrm{P}=\mathrm{C}\left(\mathrm{CH}_{3}\right) \mathrm{CO}_{2} \mathrm{C}_{2} \mathrm{H}_{5}$ /benzene; n, DIBAH/THF; o, $5 \%$ aq. $\mathrm{KOH} / \mathrm{MeOH} ; \mathrm{p}, \mathrm{MnO}_{2} /$ acetone.

tane compounds were thus obtained, and out attention was turned to constructing various derivatives containing modified side chains, especially analogues of cyclonerotriol, ${ }^{11}$ whose plant growth-promoting activities have been recently suggested. ${ }^{1)}$

Although the attempted deprotonation for alkylating either $\mathbf{5}$ or $\mathbf{6}$ with lithium diisopropylamide in THF was unsuccessful, transformation of 9 and $\mathbf{1 0}$ into $\mathbf{1 1}$ and 12, respectively, involved the rather straightforward chemistry shown in Schemes 3 and 4. Oxidation of 9 with PCC gave an aldehyde (13), which in turn was reacted with a stable ylide to give a trans $\alpha, \beta$ - unsaturated ester (14; olefinic protons, $5.79 \mathrm{~d}$, $7.09 \mathrm{~d}, J=16 \mathrm{~Hz}$ ). Hydrogenation of $\mathbf{1 4}$ and subsequent reduction with $\mathrm{LiAlH}_{4}$ provided an elongated alcohol (16) without any difficulties. Further oxidation of $\mathbf{1 6}$ to an aldehyde (17) was affected again with PCC, and the resulting 17 was coupled further with a propionate unit by the Wittig reaction. Reduction of the resulting ester (18) was conducted with DIBAH in THF to produce 11 in a $32 \%$ yield. The stereochemistry of the side chain double bond was assigned to be an $E$ configuration by comparing the ${ }^{13} \mathrm{C}$-NMR spectrum of $\mathbf{1 1}$ with cyclonerotriol. Thus, olefinic carbon signals 
were observed at $126.4 \mathrm{ppm}$ and $134.6 \mathrm{ppm}$ in 11, those of cyclonerotriol being at $126.9 \mathrm{ppm}$ and $135.8 \mathrm{ppm} .{ }^{11)}$ Hydroxymethyl signals were found at $68.8 \mathrm{ppm}$ in both cases.

The stereoisomer $\mathbf{1 0}$ was transformed in practically the same way to the series of compounds shown in Scheme 4.

A carboxylic acid (25) and an aldehyde (26) were also prepared from the intermediary $\mathbf{2 4}$ and 12 , respectively.

These compounds so far prepared include a unique 2-oxabicyclo[2,2,1]heptane system with a sesquiterpene-like carbon skeleton and are being currently subjected to biological assays, which will be reported elsewhere.

\section{EXPERIMENTAL}

Melting points $(\mathrm{mp})$ were measured on a Yanagimoto BY-1 hot stage apparatus and are uncorrected. Infrared spectra were measured on a JASCO IR-810 spectrophotometer. Proton NMR spectra were recorded on either a JEOL FX-200 $(200 \mathrm{MHz})$ or a JEOL GX-400 $(400 \mathrm{MHz})$ spectrometer, and all the chemical shifts are reported as $\delta$ ppm from the TMS internal standard in a $\mathrm{CDCl}_{3}$ solvent. Carbon-13 NMR spectra were recorded at $50 \mathrm{MHz}$ on a JEOL FX-200 spectrometer unless otherwise stated, and the chemical shifts were calculated from the central signal of the $\mathrm{CDCl}_{3}$ solvent as $77.0 \mathrm{ppm}$. Electron ionization MS were taken on a Shimadzu-LKB 9020DF spectrometer at an ionization potential of $70 \mathrm{eV}$, and high-resolution MS were obtained on a Hitachi M80-B spectrometer. Silica gel column chromatography was conducted using Kieselgel 60 (Merck, $230 \sim 400$ mesh).

Plinol C (2). In an autoclave, $26.10 \mathrm{~g}(0.15 \mathrm{~mol})$ of linalool (1) was pressurized with nitrogen gas to an initial pressure of $90 \mathrm{~atm}$. The pyrolytic reaction was carried out by heating at $250^{\circ} \mathrm{C}$ for $12 \mathrm{hr}$, during which the internal pressure was raised to $150 \mathrm{~atm}$. After cooling, the reaction products were separated by silica gel column chromatography, using $n$-hexane-ether $(3: 1)$ as the eluent, to give $3.5 \mathrm{~g}$ of a less polar mixture of the dehydration products and $25.0 \mathrm{~g}$ of a plinol-containing fraction. The plinolcontaining fraction $(865.4 \mathrm{mg})$ was further chromatographed on silica gel using the same solvent system to give, along with $63.8 \mathrm{mg}$ of recovered 1 and $228.7 \mathrm{mg}$ of crystalline plinol $\mathrm{D}\left(3, \mathrm{mp} 67^{\circ} \mathrm{C}\right), 436.2 \mathrm{mg}$ of oily plinol $\mathrm{C}$ (2) in a $41.6 \%$ yield; IR (neat): $3580,3500 \sim 3100,2960$, $2870,1638,1445,1375$ and $1090 \mathrm{~cm}^{-1}$; ${ }^{1} \mathrm{H}-\mathrm{NMR}(200$ $\mathrm{MHz}): 0.81(3 \mathrm{H}, \mathrm{d}, J=8.0 \mathrm{~Hz}), 1.35(3 \mathrm{H}, \mathrm{s}), 1.60 \sim 2.04$ $(5 \mathrm{H}), 1.75(3 \mathrm{H}, \mathrm{s}), 2.64(1 \mathrm{H}, \mathrm{q}), 4.68(1 \mathrm{H}, \mathrm{s})$ and $4.84 \mathrm{ppm}$ (1H, s); ${ }^{13}$ C-NMR: 9.3, 23.3, 25.3, 29.4, 39.3, 45.2, 48.7, $80.2,110.5$ and $146.5 \mathrm{ppm}$.
Treatment of $\mathbf{2}$ with $\mathrm{N}$-iodosuccinimide. To a solution of $2(109.8 \mathrm{mg}, 0.71 \mathrm{mmol})$ in $4 \mathrm{ml}$ of dry acetonitrile was added $242.6 \mathrm{mg}$ of $N$-iodosuccinimide (1.08 mmol, $1.5 \mathrm{eq}$.). The mixture was stirred for $10 \mathrm{~min}$ at room temperature in a nitrogen atmosphere without exposure to the light. The excess $\mathrm{N}$-iodosuccinimide was decomposed by adding a saturated aqueous solution of $\mathrm{Na}_{2} \mathrm{SO}_{3}$. The product was extracted with ether, and the ethereal extract was successively washed with dilute hydrochloric acid, saturated aqueous $\mathrm{Na}_{2} \mathrm{SO}_{3}$ solution and brine, and then dried over anhydrous $\mathrm{MgSO}_{4}$. Filtration and stripping of the solvent under reduced pressure gave $197.4 \mathrm{mg}(0.67 \mathrm{mmol}, 95 \%$ yield) of labile $4 \mathrm{a}$ as a yellow oil; IR $\left(\mathrm{CHCl}_{3}\right): 2960,2925$, $1720,1380,1155$ and $910 \mathrm{~cm}^{-1}:{ }^{1} \mathrm{H}-\mathrm{NMR}(400 \mathrm{MHz}): 1.14$ $(3 \mathrm{H}, \mathrm{d}, J=8.0 \mathrm{~Hz}), 1.18(3 \mathrm{H}, \mathrm{s}), 1.48(3 \mathrm{H}, \mathrm{d}, J=1.22 \mathrm{~Hz})$, $1.55 \sim 1.70(3 \mathrm{H}, \mathrm{m}), 1.78 \sim 1.90(2 \mathrm{H}), 2.20(1 \mathrm{H}$, br. $), 3.10$ $(1 \mathrm{H}, \mathrm{qd}, J=1.22$ and $10 \mathrm{~Hz})$ and $3.19(1 \mathrm{H}$, br. $\mathrm{d}, J=$ $10 \mathrm{~Hz}) ;{ }^{13} \mathrm{C}-\mathrm{NMR}: 12.7,17.5,17.8,24.5,25.5,35.5,49.0$, $50.2,80.7$ and $87.6 \mathrm{ppm}$; MS: $m / z 280\left(\mathrm{M}^{+}\right), 251,153,119$, $109,95,81$ and 43 .

Treatment of 2 with $N$-bromosuccinimide. To a solution of $2(130.0 \mathrm{mg}, 0.84 \mathrm{mmol})$ in dry $\mathrm{CH}_{3} \mathrm{CN}$ was added $224.0 \mathrm{mg}$ of $\mathrm{N}$-bromosuccinimide ( $1.25 \mathrm{mmol}, 1.5 \mathrm{eq}$.), and the mixture was stirred for $5 \mathrm{~min}$ at room temperature in an $\mathrm{N}_{2}$ atmosphere without exposure to the light. Extraction and working-up as just described afforded $202.3 \mathrm{mg}$ of 4b quantitatively as a labile oil; ${ }^{1} \mathrm{H}-\mathrm{NMR}(200 \mathrm{MHz}): 1.16$ $(3 \mathrm{H}, \mathrm{d}, J=8 \mathrm{~Hz}), 1.20(3 \mathrm{H}, \mathrm{s}), 1.41(3 \mathrm{H}, \mathrm{s}), 1.50 \sim 1.92$ $(5 \mathrm{H}), 2.18(\mathrm{lH}, \mathrm{s})$ and $3.28 \mathrm{ppm}(2 \mathrm{H}$, br. $) ;{ }^{13} \mathrm{C}-\mathrm{NMR}: 12.6$, $24.5,24.7,35.6,41.2,48.5,49.4,81.2$ and $87.0 \mathrm{ppm}$.

Phenylselenoetherification of 2 . To a solution of $2(103.3$ $\mathrm{mg}, 0.67 \mathrm{mmol}$ ) in $4 \mathrm{ml}$ of dry $\mathrm{CH}_{2} \mathrm{Cl}_{2}$ was added $170.1 \mathrm{mg}$ ( 1.3 eq., $0.88 \mathrm{mmol}$ ) of phenylselenenyl chloride at $0^{\circ} \mathrm{C}$, and the mixture was stirred for $15 \mathrm{~min}$ at the same temperature. The reaction mixture was then diluted with water and extracted three times with ether. The combined extract was successively washed with saturated $\mathrm{NaHCO}_{3}$ solution and brine, and then dried over anhydrous $\mathrm{MgSO}_{4}$. Filtration and stripping of the solvent under reduced pressure yielded a crude product, which was separated by medium-pressure chromatography with a Lobar column (Merck Lichroprep Si60, 40 63 $\mu \mathrm{m}$ ) using $n$-hexane ethyl acetate $(20: 1)$ as the eluent to give $52.8 \mathrm{mg}$ of yellowish 5 (25.1\% yield); IR $\left(\mathrm{CHCl}_{3}\right): 3060,2980$, $2960,1585,1480,1210$ and $905 \mathrm{~cm}^{-1} ;{ }^{1} \mathrm{H}-\mathrm{NMR}(200$ $\mathrm{MHz}): 1.05(3 \mathrm{H}, \mathrm{d}, J=8.0 \mathrm{~Hz}), 1.20(3 \mathrm{H}, \mathrm{s}), 1.37(3 \mathrm{H}, \mathrm{s})$, $1.50 \sim 2.06(5 \mathrm{H}), 2.17(1 \mathrm{H}, \mathrm{br}),. 2.97(1 \mathrm{H}, \mathrm{d}, J=11.4 \mathrm{~Hz})$, $3.34(1 \mathrm{H}, \mathrm{d}, J=11.4 \mathrm{~Hz}), 7.22(3 \mathrm{H}, \mathrm{m}$, aromatic) and 7.50 ppm (2H, m, aromatic); ${ }^{13} \mathrm{C}-\mathrm{NMR}: 12.8,17.4,25.2,26.4$, $35.8,40.3,48.6,50.1,82.3,86.3,128.6,128.8,129.0,131.4$, 132.2 and $132.8 \mathrm{ppm}$; EI-MS (70 eV): $m / z 309\left(\mathrm{M}^{+}\right), 214$, $171,139,95$ and 43. Continued elution afforded, after removing the solvent, $69.1 \mathrm{mg}$ of a yellow oil of $6(32.9 \%$ yield); IR $\left(\mathrm{CHCl}_{3}\right): 3060,2980,2960,1580,1480,1385$ and $910 \mathrm{~cm}^{-1} ;{ }^{1} \mathrm{H}-\mathrm{NMR}(200 \mathrm{MHz}): 1.14(3 \mathrm{H}, \mathrm{d}, J=8 \mathrm{~Hz})$, 
$1.20(3 \mathrm{H}, \mathrm{s}), 1.38(3 \mathrm{H}, \mathrm{s}), 1.50 \sim 2.06(5 \mathrm{H}), 2.18(1 \mathrm{H}, \mathrm{br}$.$) ,$ $3.02(1 \mathrm{H}, \mathrm{d}, J=11 \mathrm{~Hz}), 3.12(1 \mathrm{H}, \mathrm{d}, J=11 \mathrm{~Hz}), 7.22(3 \mathrm{H}$, $\mathrm{m})$ and $7.50 \mathrm{ppm}(2 \mathrm{H}, \mathrm{m}) ;{ }^{13} \mathrm{C}-\mathrm{NMR}: 12.5,17.3,25.0$, $26.4,35.4,40.4,48.4,50.1,81.4,86.4,126.6,128.8,129.0$, 131.4, 132.2 and 132.8 ppm; EI-MS: $m / z 309\left(\mathrm{M}^{+}\right), 214$, $171,139,95$ and 43 .

Epoxydation and etherification. To a solution of $\mathbf{2}$ $(4.536 \mathrm{~g}, 29.4 \mathrm{mmol})$ in $70 \mathrm{ml}$ of dried $\mathrm{CH}_{2} \mathrm{Cl}_{2}$ was added $5.8 \mathrm{~g}$ of meta-chloroperbenzoic acid (mCPBA, $85 \%$ purity, $28.6 \mathrm{mmol}$ ), and the mixture was stirred at room temperature for $2 \mathrm{hr}$. An additional $1 \mathrm{~g}$ of mCPBA was then added and stirring was continued for a further 1 hr. The reaction mixture was diluted with ethyl acetate and treated with saturated aq. $\mathrm{NaHCO}_{3}$. The aqueous layer was further extracted twice with ethyl acetate, before the organic extracts were combined, washed again with saturated aq. $\mathrm{NaHCO}_{3}$ and brine, and then dried over anhyd. $\mathrm{MgSO}_{4}$. Filtration and stripping of the solvent gave $5.09 \mathrm{~g}$ of a stereoisomeric mixture of epoxide products, the ratio of which was estimated by its ${ }^{1} \mathrm{H}-\mathrm{NMR}$ spectrum. The intensities of the doublet methyl signals at $0.96 \mathrm{ppm}$ and 1.14 ppm were almost same, and those of epoxide methylene groups (2.49 and $2.64 \mathrm{ppm}$ ) and (2.54 and $2.78 \mathrm{ppm})$ also appeared in equal intensities.

To a solution of the epoxide mixture $(5.09 \mathrm{~g}, 29.9 \mathrm{mmol})$ in $25 \mathrm{ml}$ of $\mathrm{CH}_{2} \mathrm{Cl}_{2}$ was added pyridinium $p$-toluenesulfonate $(937.5 \mathrm{mg}, 12 \mathrm{~mol} \%$ ) and the mixture was stirred at room temperature for $30 \mathrm{~min}$. To the reaction mixture was added a small volume of water, and the whole was extracted with $\mathrm{CH}_{2} \mathrm{Cl}_{2}$. The organic extract was successively washed with $2 \mathrm{~N} \mathrm{HCl}$, aq. sat. $\mathrm{NaHCO}_{3}$ and brine, and then dried over anhyd. $\mathrm{MgSO}_{4}$. Filtration and stripping of the solvent under reduced pressure provided $4.51 \mathrm{~g}$ of an oily mixture of products. A portion of this oil $(1.52 \mathrm{~g})$ was successively purified by column chromatography on silica gel, using $n$-hexane-ethyl acetate $(2: 1)$ as the eluent and by medium-pressure liquid chromatography on a Lobar colum (Merck, Lichroprep Si60, 40 63 $\mu \mathrm{m}$ ) using $n$-hexane ethyl acetate (4:1) to give $191 \mathrm{mg}(11.2 \%$ yield) of the colorless oil of an alcohol 9; IR $\left(\mathrm{CHCl}_{3}\right): 3600$, $3580 \sim 3300,2970,1460,1380,1240,1030$ and $905 \mathrm{~cm}^{-1}$; ${ }^{1} \mathrm{H}-\mathrm{NMR}(200 \mathrm{MHz}): 1.07(3 \mathrm{H}, \mathrm{d}, J=7.3 \mathrm{~Hz}), 1.21(3 \mathrm{H}, \mathrm{s})$, $1.28(3 \mathrm{H}, \mathrm{s}), 1.42 \sim 1.80(5 \mathrm{H}), 1.94(1 \mathrm{H}, \mathrm{br}), 3.22(1 \mathrm{H}, \mathrm{d}$, $J=10.3 \mathrm{~Hz})$ and $3.67 \mathrm{ppm}(1 \mathrm{H}, \mathrm{d}, J=10.7 \mathrm{~Hz})$ MS: $m / z$ $170\left(\mathrm{M}^{+}\right), 152,139,113,95,76,55$ and 43. Anal. Found: C, 69.83; H, 10.58. Calcd. for $\mathrm{C}_{10} \mathrm{H}_{18} \mathrm{O}_{2}: \mathrm{C}, 70.53 ; \mathrm{H}$, $10.58 \%$.

Continued elution of the column with $n$-hexane-ethyl acetate $(2: 1)$ afforded $623 \mathrm{mg}(36.3 \%$ yield) of the colorless oil of an alcohol (10); IR $\left(\mathrm{CHCl}_{3}\right): 3620,3580 \sim$ $3300,2970,1460,1380,1310,1240,1080,1040$ and $905 \mathrm{~cm}^{-1} ;{ }^{1} \mathrm{H}-\mathrm{NMR}(200 \mathrm{MHz}): 1.13(3 \mathrm{H}, \mathrm{d}, J=7.4 \mathrm{~Hz})$, $1.22(3 \mathrm{H}, \mathrm{s}), 1.30(3 \mathrm{H}, \mathrm{s}), 1.40 \sim 1.80(5 \mathrm{H}), 2.05(1 \mathrm{H}, \mathrm{br}$.$) ,$ $3.45(1 \mathrm{H}, \mathrm{d}, J=10.3 \mathrm{~Hz})$ and $3.54 \mathrm{ppm}(1 \mathrm{H}, \mathrm{d}, J=$ $10.3 \mathrm{~Hz}) ;{ }^{13} \mathrm{C}-\mathrm{NMR}: 12.4,17.1,23.8,24.2,35.6,48.1,49.0$, 69.3, 81.3 and 85.6 ppm; MS: $m / z 170\left(\mathrm{M}^{+}\right), 152,139,113$,
95, 76, 55 and 43. Anal. Found: C, 70.30; H, 10.25. Calcd. for $\mathrm{C}_{10} \mathrm{H}_{18} \mathrm{O}_{2}: \mathrm{C}, 70.53 ; \mathrm{H}, 10.58 \%$.

$\left(3 S^{*}, 7 S^{*}\right)$-3-Formyl-1,3,7-trime thyl-2-oxabicyclo$[2,2,1]$ heptane (13). To a solution of $9(410 \mathrm{mg}, 2.41$ mmol) in $15 \mathrm{ml}$ of $\mathrm{CH}_{2} \mathrm{Cl}_{2}$ was added $1.3 \mathrm{~g}$ of pyridinium chlorochromate $(5.28 \mathrm{mmol})$ and the mixture was vigorously stirred for $40 \mathrm{~min}$ in an $\mathrm{N}_{2}$ atmosphere at $0^{\circ} \mathrm{C}$. The mixture was diluted with $100 \mathrm{ml}$ of ether and the organic layer was passed through a column of Florisil $(60 \sim 100$ mesh) using ether as the eluent. The eluate was evaporated to dryness under reduced pressure to give $350 \mathrm{mg}(2.08$ mmol, $86.4 \%$ yield) of an oily aldehyde (13); ${ }^{1} \mathrm{H}-\mathrm{NMR}$ $(200 \mathrm{MHz}): 0.74(3 \mathrm{H}, \mathrm{d}, J=6.9 \mathrm{~Hz}), 1.18(3 \mathrm{H}, \mathrm{s}), 1.25(3 \mathrm{H}$, s), $1.55 \sim 1.82(5 \mathrm{H}), 2.47(1 \mathrm{H}, \mathrm{br})$ and $9.61 \mathrm{ppm}(1 \mathrm{H}, \mathrm{s})$ : MS: $m / z 168\left(\mathrm{M}^{+}\right), 139,128,113,99,85$ and 43 .

$\left(3 S^{*}, 7 S^{*}\right)-3-[2-E t h o x y c a r b o n y l e t h e n y l]-1,3,7-t r i m e t h y /-$ 2-oxabicyclo/ 2,2,1/heptane (14). To a solution of 13 (350 $\mathrm{mg}, 2.08 \mathrm{mmol}$ ) in $4 \mathrm{ml}$ of benzene was added ethoxycarbonylmethylene triphenylphosphorane $(1.1 \mathrm{~g}, 3.1$ $\mathrm{mmol}$ ) and the mixture was heated under reflux for $3 \mathrm{hr}$ in an $\mathrm{N}_{2}$ atmosphere. Water was added to the mixture, which was then extracted with ethyl acetate. The extract was successively washed with $2 \mathrm{~N} \mathrm{HCl}$, aq. sat. $\mathrm{NaHCO}_{3}$ solution and brine, and dried over anhyd. $\mathrm{MgSO}_{4}$. Filtration and stripping of the solvent afforded a pale yellowish oil, which was purified by column chromatography on silica gel, using $n$-hexane-ethyl acetate ( $7: 1$ ) as the eluent, to give, after evaporating the solvent and drying, $349 \mathrm{mg}$ $(1.47 \mathrm{mmol}, 70.7 \%$ yield $)$ of 14; IR $\left(\mathrm{CHCl}_{3}\right): 2960,2920$, $1705,1645,1450,1380,1365,1300,1275,1180,1040$ and $905 \mathrm{~cm}^{-1}$; ${ }^{1} \mathrm{H}-\mathrm{NMR}(200 \mathrm{MHz}): 0.88(3 \mathrm{H}, \mathrm{d}, J=7.5 \mathrm{~Hz})$, $1.23(3 \mathrm{H}, \mathrm{s}), 1.27(3 \mathrm{H}, \mathrm{s}), 1.31(3 \mathrm{H}, \mathrm{t}, J=7.1 \mathrm{~Hz}), 1.48 \sim$ $1.95(5 \mathrm{H}), 2.12(1 \mathrm{H}$, br. $), 4.19(2 \mathrm{H}, \mathrm{q}, J=7.1 \mathrm{~Hz}), 5.79(1 \mathrm{H}$, $\mathrm{d}, J=16 \mathrm{~Hz})$, and $7.09 \mathrm{ppm}(1 \mathrm{H}, \mathrm{d}, J=16 \mathrm{~Hz})$; MS: $m / z$ : $238\left(\mathrm{M}^{+}\right), 209,180,168,139,121,107,95,81,69$ and 43.

$\left(3 S^{*}, 7 S^{*}\right)$-3-[2-Ethoxycarbonylethyl]-1,3,7-trimethyl-2oxabicyclo[2,2,I Jheptane (15). To a solution of 14 (330 $\mathrm{mg}, 1.38 \mathrm{mmol}$ ) in $10 \mathrm{ml}$ of ethyl acetate was added $900 \mathrm{mg}$ of $5 \% \mathrm{Pd}-\mathrm{C}$ (Kawaken Fine Chemicals $\mathrm{Co}$.) and the mixture was stirred in an $\mathrm{H}_{2}$ atmosphere for $2 \mathrm{hr}$ at room temperature. The mixture was filtered through a bed of Celite 545 to remove the catalyst, which was washed thoroughly with ethyl acetate. The combined filtrate and washings were evaporated and dried in vacuo to give $292 \mathrm{mg}$ of $15(1.21 \mathrm{mmol}, 87.7 \%$ yield $)$; IR $\left(\mathrm{CHCl}_{3}\right): 2960$, $1725,1450,1380,1090$ and $910 \mathrm{~cm}^{-1} ;{ }^{1} \mathrm{H}-\mathrm{NMR}(200$ $\mathrm{MHz}): 1.09(3 \mathrm{H}, \mathrm{d}, J=6.8 \mathrm{~Hz}), 1.17(3 \mathrm{H}, \mathrm{s}), 1.18(3 \mathrm{H}, \mathrm{s})$, $1.25(3 \mathrm{H}, \mathrm{t}, J=6.8 \mathrm{~Hz}), 1.40 \sim 1.92(7 \mathrm{H}), 1.98$ (1H, br.), 2.32 and $2.50(2 \mathrm{H}, \mathrm{m})$, and $4.12 \mathrm{ppm}(2 \mathrm{H}, \mathrm{q}, J=6.8 \mathrm{~Hz})$; MS: $m / z 240\left(\mathrm{M}^{+}\right)$and 211. Anal. Found: C, 70,17; $\mathrm{H}$, 10.01. Calcd. for $\mathrm{C}_{14} \mathrm{H}_{24} \mathrm{O}_{3}: \mathrm{C}, 69.96 ; \mathrm{H}, 10.07 \%$.

(3S*,7S*)-3-[3-Hydroxypropyl]-1,3,7-trime thyl-2oxabicyclo[2,2,1 Jheptane (16). To a solution of 15 (286 
$\mathrm{mg}, 1.19 \mathrm{mmol}$ ) in $6 \mathrm{ml}$ of THF was added $72 \mathrm{mg}$ of $\mathrm{LiAlH}_{4}$, and the mixture was stirred for $10 \mathrm{~min}$ in an $\mathrm{N}_{2}$ atmosphere at room temperature. The reaction was quenched by adding water, and the mixture was extracted twice with $50 \mathrm{ml}$ portions of ethyl acetate. The organic layer was washed with $2 \mathrm{~N} \mathrm{HCl}$, aq. sat. $\mathrm{NaHCO}_{3}$ and brine, and then dried over anhyd. $\mathrm{MgSO}_{4}$. Filtration and evaporation of the solvent afforded $214 \mathrm{mg}$ of $16(1.08 \mathrm{mmol}, 90.0 \%$ yield); IR $\left(\mathrm{CHCl}_{3}\right): 3620,3580 \sim 3200,2960,1730,1460$, $1375,1230,1085$ and $905 \mathrm{~cm}^{-1} ;{ }^{1} \mathrm{H}-\mathrm{NMR}(200 \mathrm{MHz}): 1 . \mathrm{I}$ $(3 \mathrm{H}, \mathrm{d}, J=7.2 \mathrm{~Hz}), 1.20(3 \mathrm{H}, \mathrm{s}), 1.21(3 \mathrm{H}, \mathrm{s}), 1.40 \sim 1.92$ $(9 \mathrm{H}), 1.97(1 \mathrm{H}, \mathrm{br}),. 2.80(\mathrm{H}, \mathrm{br}, \mathrm{OH})$ and $3.60 \mathrm{ppm}(2 \mathrm{H}$, m); MS: $m / z 198\left(\mathrm{M}^{+}\right), 180$ and 169. Anal. Found: C, 72.44; $\mathrm{H}, 10.95$. Calcd. for $\mathrm{C}_{12} \mathrm{H}_{22} \mathrm{O}_{2}: \mathrm{C}, 72.73 ; \mathrm{H}, 11.11 \%$.

$\left(3 S^{*}, 7 S^{*}\right)$-3-[3-Formylethyl]-1,3,7-trimethyl-2-oxabicyclo/2,2,I]heptane (17). To a solution of $\mathbf{1 6}(214 \mathrm{mg}, 1.08$ $\mathrm{mmol}$ ) in $10 \mathrm{ml}$ of $\mathrm{CH}_{2} \mathrm{Cl}_{2}$ was added $500 \mathrm{mg}$ of pyridinium chlorochromate (PCC, $2.03 \mathrm{mmol}$ ) and the mixture was stirred for $30 \mathrm{~min}$ at room temperature in an $\mathrm{Ar}$ atmosphere. The mixture was diluted with dry ether $(50 \mathrm{ml})$ and passed through a column of Florisil $(60 \sim 100$ mesh), the column being washed with ether. The eluate and washings were combined and purged of solvent under reduced pressure to give $209 \mathrm{mg}$ of $17(1.06 \mathrm{mmol}, 98.1 \%$; IR $\left(\mathrm{CHCl}_{3}\right): 2960,2840,2730,1725,1450,1380,1235$, 1090 and $910 \mathrm{~cm}^{-1} ;{ }^{1} \mathrm{H}-\mathrm{NMR}(200 \mathrm{MHz}): 1.07(3 \mathrm{H}, \mathrm{d})$, $J=7.8 \mathrm{~Hz}), 1.17(3 \mathrm{H}, \mathrm{s}), 1.18(3 \mathrm{H}, \mathrm{s}), 1.40 \sim 1.92(7 \mathrm{H}), 2.00$ (1H, br.), $2.50 \sim 2.64(2 \mathrm{H}, \mathrm{m})$ and $9.83 \mathrm{ppm}(1 \mathrm{H}, \mathrm{s})$; MS: $m / z 196\left(\mathrm{M}^{+}\right), 153,139,123,95,81,55$ and 43 .

(3S*,7S*)-3-[4-Ethoxycarbonylpent-3-enyl]-I,3,7trimethyl-2-oxabicyclo[2,2,1 Jheptane (18). To a solution of $17(63 \mathrm{mg}, 0.31 \mathrm{mmol})$ in $8 \mathrm{ml}$ of benzene was added 1 ethoxycarbonylethylidene triphenylphosphorane $(156 \mathrm{mg}$, $0.43 \mathrm{mmol}$ ) and the mixture was stirred overnight at room temperature. The mixture was evaporated to dryness and the residue was chromatographed over silica gel using $n$ hexane-ethyl acetate $(7: 1)$ as the eluent. Appropriate fractions, as judged by TLC, were combined and evaporated to dryness to give $61 \mathrm{mg}$ of $18(0.22 \mathrm{mmol}, 68.5 \%)$; UV $(\mathrm{MeOH}): 220.4 \mathrm{~nm}(\varepsilon 10,360)$; IR $\left(\mathrm{CHCl}_{3}\right): 2980,1700$, $1645,1445,1380,1370,1275,1245,1155,1095$ and 910 $\mathrm{cm}^{-1} ;{ }^{1} \mathrm{H}-\mathrm{NMR}(200 \mathrm{MHz}): 1.07(3 \mathrm{H}, \mathrm{d}, J=7.0 \mathrm{~Hz}), 1.20$ $(3 \mathrm{H}, \mathrm{s}), 1.21(3 \mathrm{H}, \mathrm{s}), 1.31(3 \mathrm{H}, \mathrm{t}, J=7.3 \mathrm{~Hz}), 1.40 \sim 1.96$ $(9 \mathrm{H}), 1.98(1 \mathrm{H}, \mathrm{br}), 4.18(2 \mathrm{H}, \mathrm{q}, J=7.3 \mathrm{~Hz})$ and $6.74 \mathrm{ppm}$ $(1 \mathrm{H}, \mathrm{t}, J=7.9 \mathrm{~Hz}) ;{ }^{13} \mathrm{C}-\mathrm{NMR}: 12.2,12.6,14.3,17.4,230$, $24.7,25.3,35.6,39.0,48.4,50.5,60.3,80.6,85.5,127.5$, 142.3 and 168.1 ppm; MS: $m / z$ 251, 235, 208, 139, 95, 81, 55 and 43.

(3S*,7S*)-3-[5-Hydroxy-4-methylpent-3-enyl]-1,3,7trimethyl-2-oxabicyclo/2,2,1]heptane (11). To a solution of $16(227 \mathrm{mg})$ in $2 \mathrm{ml}$ of THF was added $1.35 \mathrm{ml}$ of diisobutylaluminum hydride $(25 \mathrm{w} / \mathrm{v} \%$ in hexane $)$ and the mixture was stirred for $1 \mathrm{hr}$ at $-78^{\circ} \mathrm{C}$. The mixture was then warmed up to room temperature and water was added. The whole was extracted with ether and the organic extract was washed with $2 \mathrm{~N} \mathrm{HCl}$, sat. aq. $\mathrm{NaHCO}_{3}$ and brine, and then dried over anhyd. $\mathrm{MgSO}_{4}$. Filtration and evaporation of the solvent afforded an oily residue, which was chromatographed through silica gel using $n$-hexane-ethyl acetate $(2: 1)$ to yield, after removing the solvent, $63 \mathrm{mg}$ of $11\left(32.4 \%\right.$ yield); ${ }^{1} \mathrm{H}-\mathrm{NMR}(200 \mathrm{MHz}): 1.08(3 \mathrm{H}$, $\mathrm{d}, J=7.4 \mathrm{~Hz}), 1.20(3 \mathrm{H}, \mathrm{s}), 1.21(3 \mathrm{H}, \mathrm{s}), 1.40 \sim 2.20(10 \mathrm{H})$, $3.99(2 \mathrm{H}, \mathrm{br}$.$) and 5.39 \mathrm{ppm}(1 \mathrm{H}, \mathrm{t}, J=7.0 \mathrm{~Hz}) ;{ }^{13} \mathrm{C}-\mathrm{NMR}$ $(100 \mathrm{MHz}): 12.6,13.5,17.3,22.1,24.7,25.4,35.6,40.3$, $48.5,50.2,68.8,81.1,85.4,126.4$ and $134.6 \mathrm{ppm}$; HRMS: Found, $m / z 238.1938\left(\mathrm{M}^{+}\right)$; Calcd. for $\mathrm{C}_{15} \mathrm{H}_{26} \mathrm{O}_{2}$, 238.1934.

(3R*,7S*)-3-Formyl-1,3,7-trimethyl-2-oxabicyclo/2,2,1]-heptane (19). To a solution of $10(1.36 \mathrm{~g}, 8.0 \mathrm{mmol})$ in $40 \mathrm{ml}$ of $\mathrm{CH}_{2} \mathrm{Cl}_{2}$ was added $3.6 \mathrm{~g}$ of $\mathrm{PCC}(13.6 \mathrm{mmol}$, 1.7 eq.) and the mixture was stirred for $20 \mathrm{~min}$. After a further addition of PCC ( $1.5 \mathrm{eq})$, stirring was continued for $1 \mathrm{hr}$. The mixture was diluted with ether and the whole was passed through a column of Florisil. The eluate and washings were combined and stripped of solvent to give $1.25 \mathrm{~g}$ of $19(7.41 \mathrm{mmol}, 92.6 \%) ;{ }^{1} \mathrm{H}-\mathrm{NMR}(200 \mathrm{MHz})$ : $1.14(3 \mathrm{H}, \mathrm{d}, J=6.8 \mathrm{~Hz}), 1.31(3 \mathrm{H}, \mathrm{s}), 1.33(3 \mathrm{H}, \mathrm{s}), 1.40 \sim$ $1.82(5 \mathrm{H}), 2.26(1 \mathrm{H}, \mathrm{br}$.$) and 9.71 \mathrm{ppm}(1 \mathrm{H}, \mathrm{s})$; MS: $m / z$ $168\left(\mathrm{M}^{+}\right), 139,113,99,85$ and 43.

(3R*,7S*)-3-[2-Ethoxycarbonylethenyl]-1,3,7-trimethyl-2-oxabicyclo[2,2,1]heptane $(\mathbf{2 0})$. To a solution of $19(683 \mathrm{mg}, 40.7 \mathrm{mmol})$ in $10 \mathrm{ml}$ of benzene was added $2.0 \mathrm{~g}$ of ethoxycarbonylmethylene triphenylphosphorane (5.73 mmol, 1.4 eq.) and the mixture was heated under reflux for $1 \mathrm{hr}$. The mixture was evaporated to dryness, and the residue was purified through a column of silica gel using $n$-hexane-ethyl acetate $(10: 1 \sim 7: 1)$. Appropriate fractions were judged by TLC, combined and evaporated to dryness to give $757 \mathrm{mg}$ of $\mathbf{2 0}(3.18 \mathrm{mmol}, 78.2 \%)$ IR $\left(\mathrm{CHCl}_{3}\right): 2950,1700,1645,1360,1295,1275,1170,1025$ and $895 \mathrm{~cm}^{-1} ;{ }^{1} \mathrm{H}-\mathrm{NMR}(200 \mathrm{MHz}): 1.14(3 \mathrm{H}, \mathrm{d}, J=$ $6.8 \mathrm{~Hz}), 1.27(3 \mathrm{H}, \mathrm{s}), 1.29(3 \mathrm{H}, \mathrm{s}), 1.29(3 \mathrm{H}, \mathrm{t}, J=7.1 \mathrm{~Hz})$, $1.40 \sim 1.80(5 \mathrm{H}), 2.15(1 \mathrm{H}$, br. $), 4.19(2 \mathrm{H}, \mathrm{q}, J=7.1 \mathrm{~Hz})$, $6.17(1 \mathrm{H}, \mathrm{d}, J=15.7 \mathrm{~Hz})$ and $7.01 \mathrm{ppm}(1 \mathrm{H}, \mathrm{d}, J=$ $15.7 \mathrm{~Hz})$; MS: $m / z 238\left(\mathrm{M}^{+}\right), 223,209,139,121,95,81$ and 43. Anal. Found: C, 70.42; $\mathrm{H}, 9.34$. Calcd. for $\mathrm{C}_{14} \mathrm{H}_{22} \mathrm{O}_{3}$ : C, $70.55 ; \mathrm{H}, 9.31 \%$.

$\left(3 R^{*}, 7 S^{*}\right)$-3-[2-Ethoxycarbonylethyl]-1,3,7-trimethyl2-oxabicyclo[2,2,1]heptane (21). A mixture of $720 \mathrm{mg}$ $(3.0 \mathrm{mmol})$ of $20,10 \mathrm{ml}$ of ethyl acetate and $739 \mathrm{mg}$ of $10 \%$ $\mathrm{Pd}-\mathrm{C}$ (Kawaken Fine Chemicals Co.) was stirred in an $\mathrm{H}_{2}$ atmosphere for $2 \mathrm{hr}$ at room temperature. The catalyst was removed by passing the reaction mixture through a column of silica gel. The combined filtrate and washings were purged of solvent under reduced pressure to afford a residue, which was purified by a column of silica gel using $n$-hexane ethyl acetate $(7: 1)$ as the eluent. Fractions were collected and examined by TLC. Appropriate fractions 
were combined and evaporated to dryness to afford 420 $\mathrm{mg}$ of $21(1.75 \mathrm{mmol}, 57.8 \%)$; IR $\left(\mathrm{CHCl}_{3}\right): 2980,1725$, $1380,1300,1180,1090$ and $915 \mathrm{~cm}^{-1} ;{ }^{1} \mathrm{H}-\mathrm{NMR}(200$ $\mathrm{MHz}): 1.11(3 \mathrm{H}, \mathrm{d}, J=7.4 \mathrm{~Hz}), 1.19(3 \mathrm{H}, \mathrm{s}), 1.21(3 \mathrm{H}, \mathrm{s})$, $1.26(3 \mathrm{H}, \mathrm{t}, J=7.3 \mathrm{~Hz}), 1.40 \sim 1.90(7 \mathrm{H}), 1.97(1 \mathrm{H}, \mathrm{br}$ ), $2.30(2 \mathrm{H}, \mathrm{m})$ and $4.13 \mathrm{ppm}(2 \mathrm{H}, \mathrm{q}, J=7.3 \mathrm{~Hz}) ; \mathrm{MS}: m / z$ $240\left(\mathrm{M}^{+}\right), 222,211,195,169,139,123,99,81,55$ and 43.

(3R*,7S*)-3-[3-Hydroxypropyl]-1,3,7-trimethyl-2oxabicyclo/2,2,1/heptane (22). To a solution of $21(626$ $\mathrm{mg}, 2.63 \mathrm{mmol}$ ) in $10 \mathrm{ml}$ of dry THF was added $82 \mathrm{mg}$ of $\mathrm{LiAlH}_{4}$, and the mixture was stirred for $20 \mathrm{~min}$ in an $\mathrm{N}_{2}$ atmosphere at room temperature. The excess $\mathrm{LiAlH}_{4}$ was decomposed by adding water, and the whole was extracted twice with $50 \mathrm{ml}$ portions of ethyl acetate. The combined organic extract was successively washed with $2 \mathrm{~N} \mathrm{HCl}$, aq. sat. $\mathrm{NaHCO}_{3}$ and brine, and then dried over anhyd. $\mathrm{MgSO}_{4}$. Filtration and stripping of the solvent afforded $514 \mathrm{mg}$ of $22(2.6 \mathrm{mmol}, 98.7 \%)$; IR $\left(\mathrm{CHCl}_{3}\right): 3830,3400$, $2960,1450,1380,1240,1065,1015$ and $915 \mathrm{~cm}^{-1} ;{ }^{1} \mathrm{H}-$ NMR (200 MHz): $1.12(3 \mathrm{H}, \mathrm{d}, J=7.3 \mathrm{~Hz}), 1.20(3 \mathrm{H}, \mathrm{s})$, $1.24(3 \mathrm{H}, \mathrm{s}), 1.40 \sim 1.80(7 \mathrm{H}), 1.98(1 \mathrm{H}$, br $), 2.63(1 \mathrm{H}$, br., $\mathrm{OH}), 3.65\left(2 \mathrm{H}\right.$, br., $\left.-\mathrm{CH}_{2} \mathrm{OH}\right)$; MS: $m / z 198\left(\mathrm{M}^{+}\right), 169$, 151, 139, 109, 96, 85, 81 and 43. Anal. Found: C, 72.90; H, 11.28. Calcd. for $\mathrm{C}_{12} \mathrm{H}_{22} \mathrm{O}_{2}: \mathrm{C}, 72.68 ; \mathrm{H}, 11.18 \%$.

(3R*,7S*)-3-[2-Formylethyl]-1,3,7-trimethyl-2-orabicyclo[2,2,1 /heptane (23). To a solution of $22(344 \mathrm{mg}$, $1.73 \mathrm{mmol})$ in $6 \mathrm{ml}$ of $\mathrm{CH}_{2} \mathrm{Cl}_{2}$ was added $1.2 \mathrm{~g}$ of $\mathrm{PCC}$ ( $4.87 \mathrm{mmol}, 2.8 \mathrm{eq}$.) and the mixture was stirred for $30 \mathrm{~min}$ in an Ar atmosphere at room temperature. The mixture was diluted with ether and the whole was passed through a column of Florisil. The column was eluted with ether and the eluate was evaporated to give a residue, which was further purified by a column of silica gel using $n$-hexaneethyl acetate $(7: 1 \sim 5: 1)$. Appropriate fractions were combined and purged of solvent to give $241 \mathrm{mg}$ of an oily $23(1.23 \mathrm{mmol}, 71.1 \%)$; IR $\left(\mathrm{CHCl}_{3}\right): 2960,2740,2730$, $1725,1445,1380,1240,1160,1090$ and $920 \mathrm{~cm}^{-1} ;{ }^{1} \mathrm{H}-$ NMR (200 MHz): $1.12(3 \mathrm{H}, \mathrm{d}, J=8.0 \mathrm{~Hz}), 1.20(3 \mathrm{H}, \mathrm{s})$, $1.21(3 \mathrm{H}, \mathrm{s}), 1.40 \sim 2.00(8 \mathrm{H}), 2.48(2 \mathrm{H}, \mathrm{m})$ and $9.80 \mathrm{ppm}$ (1H, s); MS: $m / z 196\left(\mathrm{M}^{+}\right), 167,139,123,96,81,55$ and 43. Anal. Found: C, 73.20; H, 10.00. Calcd. for $\mathrm{C}_{12} \mathrm{H}_{20} \mathrm{O}_{2}$ : C, $73.43 ; \mathrm{H}, 10.27 \%$.

$\left(3 R^{*}, 7 S^{*}\right)-3-[4-E t h o x y c a r b o n y l p e n t-3-e n y l]-1,3,7-$ trimethyl-2-oxabicyclo[2,2,1/heptane (24). To a solution of $23(223 \mathrm{mg}, 1.14 \mathrm{mmol})$ in $15 \mathrm{ml}$ of benzene was added $485 \mathrm{mg}$ of 1-ethoxycarbonylethylidene triphenylphosphorane $(1.33 \mathrm{mmol}, 1.2 \mathrm{eq})$ and the mixture was stirred overnight at room temperature. The mixture was evaporated and the residue was passed through a column of silica gel, using $n$-hexane-ethyl acetate $(7: 1)$ as the eluent to give, after removing the solvent, $212 \mathrm{mg}$ of $24(0.76$ mmol, 66.9\% yield); UV (MeOH): $221.8 \mathrm{~nm}(\varepsilon 15,120)$; IR $\left(\mathrm{CHCl}_{3}\right): 2980,1700,1645,1445,1380,1275,1250,1235$, 1155,1085 and $910 \mathrm{~cm}^{-1}$; ${ }^{1} \mathrm{H}-\mathrm{NMR}(200 \mathrm{MHz}): 1.12(3 \mathrm{H}$, d, $J=6.8 \mathrm{~Hz}), 1.20(3 \mathrm{H}, \mathrm{s}), 1.26(3 \mathrm{H}, \mathrm{s}), 1.30(3 \mathrm{H}, \mathrm{t}, J=$ $7.3 \mathrm{~Hz}), 1.40 \sim 1.90(7 \mathrm{H}), 1.98(1 \mathrm{H}, \mathrm{br}),. 2.15(2 \mathrm{H}, \mathrm{m}), 4.19$ $(2 \mathrm{H}, \mathrm{q}, J=7.3 \mathrm{~Hz})$ and $6.77 \mathrm{ppm}(1 \mathrm{H}, \mathrm{t}, J=7.3 \mathrm{~Hz}) ;{ }^{13} \mathrm{C}$ NMR: $12.3,12.8,14.2,17.3,24.6,25.0,25.6,35.5,40.1$, $48.2,50.0,60.3,81.0,85.2,127.5,141.8$ and $168.0 \mathrm{ppm}$. Anal. Found: C, $72.59 ; \mathrm{H}, 9.78$. Calcd. for $\mathrm{C}_{17} \mathrm{H}_{28} \mathrm{O}_{3}: \mathrm{C}$, $72.82 ; \mathrm{H}, 10.06 \%$.

$\left(3 R^{*}, 7 S^{*}\right)-3-[5-h y d r o x y-4-m e t h y l p e n t-3-e n y l]-1,3,7-$ trimethyl-2-oxabicyclo[2,2,1]heptane (12). To a solution $24(236 \mathrm{mg}, 0.85 \mathrm{mmol})$ in $5 \mathrm{ml}$ of THF was added $1.7 \mathrm{ml}$ of diisobutylaluminium hydride $(25 \mathrm{w} / \mathrm{v} \%$ in hexane) at $-20^{\circ} \mathrm{C}$ in an $\mathrm{Ar}$ atmosphere with stirring, which was continued for $30 \mathrm{~min}$ at the same temperature. The reaction was quenched by adding water, and the whole was extracted with ethyl acetate. The organic extract was washed with dilute $\mathrm{HCl}$ solution, sat.aq. $\mathrm{NaHCO}_{3}$ and brine, and then dried over anhyd. $\mathrm{MgSO}_{4}$. Filtration and stripping of the solvent gave a residue, which was purified through a column of silica gel, using $n$-hexane-ethyl acetate $(2: 1)$ as the eluant to afford, after removing the solvent, $180 \mathrm{mg}$ of $12(0.75 \mathrm{mmol}, 89.8 \%$ yield $)$; IR $\left(\mathrm{CHCl}_{3}\right): 3620,3450,2960,1700,1445,1380,1240,1155$, 990 and $910 \mathrm{~cm}^{-1} ;{ }^{1} \mathrm{H}-\mathrm{NMR}(200 \mathrm{MHz}): 1.12(3 \mathrm{H}, \mathrm{d}, J=$ $8.0 \mathrm{~Hz}), 1.20(3 \mathrm{H}, \mathrm{s}), 1.25(3 \mathrm{H}, \mathrm{s}), 1.40 \sim 2.20(11 \mathrm{H}), 4.01$ (2H, br.) and $5.41 \mathrm{ppm}(1 \mathrm{H}, \mathrm{t}, J=7.3 \mathrm{~Hz}) ;{ }^{13} \mathrm{C}-\mathrm{NMR}: 12.7$, $13.5,17.2,23.8,24.5,25.5,35.5,41.1,48.0,49.6,68.1,81.4$, 85.2, 125.4 and 134.4 ppm; MS: $m / z 238\left(\mathrm{M}^{+}\right), 220,209$, $191,166,139,107,95,81$ and 43 .

$\left(3 R^{*}, 7 S^{*}\right)-3-[4-F o r m y l p e n t-3-e n y l]-1,3,7$-trimethyl-2oxabicyclo/ 2,2,1 Jheptane (26). To a solution of 12 (58 mg) in $4 \mathrm{ml}$ of acetone was added $160 \mathrm{mg}$ of activated $\mathrm{MnO}_{2}$, and the mixture was stirred for $2 \mathrm{hr}$ at room temperature. The whole mixture was passed through a short column of silica gel to remove the $\mathrm{MnO}_{2}$, and the eluate was evaporated to dryness to afford $57 \mathrm{mg}$ of 26 ; IR $\left(\mathrm{CHCl}_{3}\right)$ : $2960,2830,2720,1680,1645,1445,1385,1240,1085$ and $915 \mathrm{~cm}^{-1}$; UV (MeOH): $230.5 \mathrm{~nm}(\varepsilon 5,760)$; ${ }^{1} \mathrm{H}-\mathrm{NMR}$ $(200 \mathrm{MHz}): 1.13(3 \mathrm{H}, \mathrm{d}, J=6.8 \mathrm{~Hz}), 1.21(3 \mathrm{H}, \mathrm{s}), 1.28(3 \mathrm{H}$, s), $1.40 \sim 1.80(7 \mathrm{H}), 2.00(1 \mathrm{H}$, br. $), 2.36(2 \mathrm{H}, \mathrm{m}), 6.51(1 \mathrm{H}$, $\mathrm{t}, J=6.8 \mathrm{~Hz})$ and $9.40 \mathrm{ppm}(1 \mathrm{H}, \mathrm{s}) ;{ }^{13} \mathrm{C}-\mathrm{NMR}: 9.2,12.9$, $17.4,24.6,25.4,25.7,35.6,39.9,48.3,50.1,81.1,85.6$, 139.0, 154.5 and $195.1 \mathrm{ppm}$; MS: $m / z 236\left(\mathrm{M}^{+}\right), 235,208$, $179,153,139,111,95,81,55$ and 43 .

$\left(3 R^{*}, 7 S^{*}\right)$-3-[4-Carboxypent-3-enyl]-1,3,7-trimethyl2-oxabicyclo/2,2,1 Jheptane (25). A mixture of $24(100 \mathrm{mg}$, $0.36 \mathrm{mmol}$ ), $6 \mathrm{ml}$ of $5 \% \mathrm{KOH}-\mathrm{H}_{2} \mathrm{O}$ and $4 \mathrm{ml}$ of $\mathrm{MeOH}$ was heated under reflux for $1 \mathrm{hr}$. The reaction mixture was neutralized by adding $2 \mathrm{~N} \mathrm{HCl}$ and extracted with ethyl acetate. The organic extract was washed with brine and then dried over anhyd. $\mathrm{MgSO}_{4}$. Filtration and removal of the solvent under reduced pressure afforded $90 \mathrm{mg}$ of $\mathbf{2 5}$; IR $\left(\mathrm{CHCl}_{3}\right): 3200,2960,1685,1445,1380,1290,1160$, 1085 and $915 \mathrm{~cm}^{-1}$; UV $(\mathrm{MeOH}): 211.4 \mathrm{~nm}(\varepsilon 12,630) ;{ }^{1} \mathrm{H}-$ NMR $(200 \mathrm{MHz}): 1.12(3 \mathrm{H}, \mathrm{d}, J=6.9 \mathrm{~Hz}), 1.21(3 \mathrm{H}, \mathrm{s})$, 
$1.26(3 \mathrm{H}, \mathrm{s}), 1.40 \sim 1.80(7 \mathrm{H}), 1.99(1 \mathrm{H}, \mathrm{br}),. 2.18(2 \mathrm{H}, \mathrm{m})$ and $6.91 \mathrm{ppm}(1 \mathrm{H}, \mathrm{t}, J=7.8 \mathrm{~Hz}) ;{ }^{13} \mathrm{C}-\mathrm{NMR}: 12.01,12.8$, $17.3,24.6,25.2,25.6,35.6,39.9,48.3,50.0,81.3,85.6$, $126.9,144.5$ and $173.0 \mathrm{ppm}$. Anal. Found: C, $71.29 ; \mathrm{H}$, 9.69. Calcd. for $\mathrm{C}_{15} \mathrm{H}_{24} \mathrm{O}_{3}: \mathrm{C}, 71.39 ; \mathrm{H}, 9.59 \%$.

Acknowledgment. We are grateful to Professor H. Seto and to Dr. K. Furihata of the Institute of Applied Microbiology, University of Tokyo, for measuring the NOE difference spectra.

\section{REFERENCES AND NOTES}

1) T. Ishiyama, personal communication to $\mathrm{KK}$.

2) Y. Matsuki, M. Kodama and S. Ito, Tetrahedron Lett., 1979, 2901.

3) T. Ikeda and K. Wakatsuki, J. Chem. Soc. Jpn., 57, 425 (1936).
4) H. Stricker, G. Ohloff and E. sz. Kovats, Tetrahedron Lett., 1964, 649.

5) H. Stricker, G. Ohloff and E. sz. Kovats, Helv. Chim. Acta, 50, 759 (1967).

6) W. Oppolzer and V. Sniekus, Angew. Chem. Int. Ed. Engl. 17, 476 (1978).

7) P. A! Bartlett, in "Asymmetric Synthesis," Vol. 3, Part B, ed. by J. D. Morrison, Academic Press, New York, 1984, pp. $411 \sim 454$.

8) E. Osawa and Y. Mochizuki, Kagaku (Chemistry), 40, 703 (1985).

9) K. Kondo and M. Matsumoto, Tetrahedron Lett., 1976, 4363.

10) K. C. Nicolaou, R. L. Magolda, W. J. Sipio, W. E. Barnette, Z. Lysenko and M. M. Joullie, J. Am. Chem. Soc., 102, 3784 (1980).

11) J. R. Hanson, P. B. Hitchcock and R. Nyfeler, $J$. Chem. Soc., Perkin Trans. 1, 1975, 1586. 